\title{
Insights into the information needs of women in the informal sector of Uganda
}

\author{
R. Ikoja-Odongo, J.R ${ }^{1}$. \\ Department of Library and Information Science, University of Zululand, South Africa \\ robert_ikoja@yahoo.com
}

Received: 6 April 2002

Revised: 6 May 2002

\begin{abstract}
The informal sector is a fast growing economic sector in Uganda for development and employment of most small business entrepreneurs including women in the country. This paper presents insights into the information needs and information seeking strategies of the Ugandan women in the informal sector. Their business characteristics and sources, and channels they use to access information as well as constraints they face in information seeking, have been explored and represented. Qualitative research design and methods that involved the use of critical incidence technique were largely used. One hundred and seventeen women from five districts were sampled through snowballing and disproportionate sampling techniques. This paper recommends actions to be taken to make business information available to women. More research on women related information is advocated.
\end{abstract}

\section{Introduction}

Whilst the search for a definition of the term informal sector remains sterile, it is an umbrella term for explaining a wide range of business activities through which poor people earn a living. The informal sector is part of the micro and small enterprise, which often is related to self-employment and income generation. The sector is characterised by low levels of technology, technical know-how and skills, and operated by self or with unpaid labour (Rwegasira \& Walter, 1998:8), and most of its entrepreneurs are persons with a low educational background. Although quantitative data on the sector is scarce, the Policy Paper on Micro and Small Enterprise Development estimates that there are 800,000 non-farm micro and small enterprises in Uganda, employing 1.5 million people.

An estimated $90 \%$ of Ugandan women, compared with $53 \%$ of men, are engaged in agriculture. Women's labour produces $80 \%$ of the country's food, $60 \%$ of traditional farm exports, such as coffee, cotton, sugar and tobacco, and an impressive $80 \%$ of non-traditional agricultural products (Elson \& Evers, 1997:17). According to the Ministry of Gender, Labour and Social Development (MoGLSD, 1999:40), female-headed households constitute 29\%. Women's adult literacy rate is estimated at $44.9 \%$ compared with $63.5 \%$ of the men. In public offices, women are represented with $18.8 \%$ in Parliament, $10.7 \%$ at ministerial level and more than $33 \%$ at district local government level (Snyder, 2000:32-33). Women constitute 16\% of decision-makers in government ministries (Gender Aware Country Report, 2001:8). The importance of this gender desegregated data lies in its ability to highlight gaps and deficiencies that exist in different sectors concerning the opportunities available to men and women.

However, in spite of being at the forefront of most activities, and estimated to be the majority in the informal sector, women's contribution and the level of involvement in Uganda's economy is not fully documented. This can be attributed to little research done on women's information needs and access to appropriate information in developing countries generally (Huyer 1997). In Uganda specifically, research on gender is patchy and inadequate (Keller, 1996:25). One area where this is most glaring is in research on information provision. Little has been done to document women's information needs and access to appropriate information in Uganda. Huyer (1997), contributing on this subject from the viewpoint of developing countries, makes a claim that the information revolution is bypassing women.

Ugandan women have resorted to the informal sector as a survival strategy in which they sell their labour as casual workers, employees, or petty entrepreneurs. But most significantly, they joined for two reasons: (a) low capital intensity, ease of entry and exit; and (b) because it fits in better with marriage and childbearing. It does not entail working regular hours that could make it difficult for them to perform their home duties (Basirika, 1994:85).

A situational analysis of the Ugandan society reveals that, firstly, the environment under which women operate is not adequately supportive for them to acquire information and document their own situations. The majority of

1. Dr. Robert Ikoja-Odongo, who graduated with a $\mathrm{PhD}$ at the University of Zululand in May, is a Senior Lecturer, East African School of Library and Information Science, Makerere University, P.O. Box 7062, Kampala, Uganda. 
Ugandan women are illiterate or semi- literate. They are very poor. They do not have time to look for information because they are heavily involved in family chores. Elson \& Evers (1997:28) report that women have little time to attend meetings, nor are they encouraged to participate in decision making. Married women have even more problems. Their movements more often than not are restricted by their spouses who limit their participation in information-based activities outside their homes, thinking that seminars/workshops are platforms for gossiping and promiscuity

Secondly, available information indicates that a majority of Ugandan women are disadvantaged by complete lack of information, lack of appropriate information materials in local languages, and the absence of library and information services in rural areas. Oral culture is highest among them. Ignorance of the existence of information services is also a barrier. The majority of women (Kigongo-Bukenya, 1996:17) do not know even those that exist.

Thirdly, there are organisations dealing with women information. But the problems of information documentation and dissemination are blamed on inadequate funds, limited marketing of information on women, and inappropriate methods of communicating information to women. There is inadequate capacity to identify the right information to various target groups, few professional staff to manage feminist information, and lack of relevant collections. The incidence of biased reporting and false portrayal of women and their information in the media (Ojiambo Ochieng, 1996:7) has also been noted.

Furthermore, as a problem of underdevelopment, lack of [appropriate information and communication] technology, limited information infrastructure, and other information resources hamper information dissemination in Uganda. There are a few groups that gather and process information on specific topics related to women. There are a limited number of resource centres outside the capital city (Kampala). Even these resource centres lack adequate resources (personnel, financial, technological). Much of the information is also out of date or poorly organised. Underdeveloped information infrastructure makes information delivery a problem (Musoke, 1996:13). As a result, information where it exists does not reach the targeted women due to improper communication tools, foreign languages used, messages getting misinterpreted or conflicting with existing local institutions and beliefs (Lwanga, 1996:15).

The aims of the paper are to establish the information needs and information-seeking behaviour of women in the informal sector in Uganda; identify their sources of information, in relation to information services, and the impact of using information in their business activities. It considers constraints women face in accessing information and makes suggestions to remedy those problems.

\section{Literature review}

Women's surge into entrepreneurship and activism dates from 1971 when a military dictatorship took over political power from a democratically elected government. It is a unique account that may not be the same with other African countries, but has a parallel with Korea during 1950-1953. It is an opinion expressed by Kwesiga in Snyder (2000:17) that a veritable explosion of Uganda African entrepreneurship was born out of the need to survive amidst chaos. This was later encouraged by a government-created climate favouring individual economic initiatives. During the regime of Idi Amin that lasted from 1971 to 1979, men either ran away or were killed. Women were left behind with children whom they could not see dying of hunger. They engaged in some work to feed them. In Korea, during the Korean War of 1950-1953, the war proved how strong and self-reliant women could be under the most adverse conditions (Paik, 1998). Many women had to support their families and themselves while their husbands or sons were away fighting communists. Many women even lost husbands and sons. Meanwhile the economy of Uganda was worsening at the same time. The failing economy too strengthened many peasant wives to come out of their homes to grow more food for the family and for sale. The money they obtained from these activities was spent on families and helping themselves. Some of them went to look for paid employment; others went to petty trade in the markets and in towns. There were urban women who went into exile. These included the educated group, those that were politically active in the previous regime, and wives of top government or senior officers in the security forces who ran away or were killed. In exile they learnt how to survive economically by engaging in many trades including entrepreneurship. They either found paid employment or something to sell. Upon return to Uganda after the fall of Amin, they continued with aggressive investment spirit.

Between 1979 and 1986, instability continued. Industries failed. Agriculture declined. Inflation soared. The commercial sector collapsed. Rebel activities intensified. Neighbouring countries especially Kenya and Tanzania 
became the major sources of household supplies for items like soap, sugar, salt, milk etc. After Museveni siezed power in 1986, security improved, respect for life was regained, markets opened and traders came in (Snyder 2000:21). With the earned freedom, women started travelling abroad to places like Bangkok, India, Dubai, and Rome to buy goods for resale in Uganda. During the same period, government began appointing women in important public positions. As confidence among them was growing, more women came out to do business. This short history provides an idea of the manner in which entrepreneurship culture among Ugandan women was born. But other factors played a role as well. These are discussed in the following paragraphs.

The economic restructuring that began in the late 1980s brought another set of issues that sent more women into business, including the informal sector. The size of the public service was trimmed through retrenchment, demobilisation of soldiers, voluntary retirement, and freezing of vacant posts in the civil service. In the private sector, government introduced a policy of liberalisation of trade in line with global trends. Industries were privatised. This also meant reduction of non-technical human resource. The effects of these factors on women are reported in the following paragraph.

According to national manpower surveys carried out in the late 1980 s, women comprised only $20 \%$ of formal sector workers. At that time $15 \%$ worked for government, but this proportion was decreased by reforms. In nongovernment establishments in 1989, women comprised nearly one half of those employed as clerks, messengers, cleaners and typists, but less than $10 \%$ of those in administrative and managerial positions in the Government of Uganda and the National Council for Children (GoU \& NCC 1994). Since it is these ranks that were disproportionately retrenched, these women moved into the informal sector (Keller, 1996:21). Where married men were retrenched, it is also likely that even more burden fell on their wives to earn income through alternative initiatives such as the informal sector.

The demobilisation of the military is a particular case that has contributed to the growth of the informal sector. Various studies, Birungi, 1995; Otto, 1993; Tadria, 1995 in Keller (1997: 21), document that since late 1992, Uganda has demobilised about 40,000 soldiers, of which women constitute a tiny minority. Some female veterans are reported to have found it difficult to re-integrate into their home villages. Societies perceived them as having followed an untraditional lifestyle as military personnel, and therefore unfit for marriage. Worse still, these women did not have access to land in their own right. They most likely turned into informal sector workers. Furthermore, for each male veteran who was demobilised, there were nearly four dependants, wives and children. This is in addition to their wives left behind in the villages while in active service. So the additional number came from the barracks. After demobilisation, the latter had to move to unfamiliar environments to live with in-laws, or remain in towns. Some of these women left their husbands or husbands left them when life became hard and moved to urban centres where they engaged in petty businesses. People affected by the demobilisation process ended mostly in the informal sector, as most of them did not have alternative employable skills. Women automatically joined the sector directly because the day to day needs of the household and particularly children forced them to do so.

In the rural areas women have fewer options than men for off-the-farm income earning activities or employment. It is said that women agricultural workers are mostly divorced or widowed female household heads. They are extremely poor, with no access to land and no other options than ill-paid farm work. Some of them engage in "distress selling" of their labour, undertaking piece work or giving labour for less than the local going rate, because of the urgent need for food or cash (Evans 1992). Other rural women engage in brewing and selling alcohol, processing and selling cooked food and fruit juices, and making handicrafts, in particular baskets and mats from papyrus (Mwaka et al, 1994:63). Others undertook difficult occupations like prostitution.

Meanwhile, the school system is producing entrants into the labour market but without formal employment and basic skills. For young women the sole option is getting married. A married African wife often engages in some activity to earn a living for the family. Like many of her kind, women who struggle for their survival in the informal sector are engaged in the smallest of trades, requiring the least capital, skills and training, as stated earlier by Basirika (1994). Keller's description paints a better picture of how an urban women in Kampala leads life.

They are to be seen on the side walks selling cigarettes, groundnuts and newspapers; along the roadsides reselling milk from the milk plants, and in the night markets for example. Markets which open at night, with vendors operating with dust or mud underfoot and by the light of small paraffin lamps (made by men in the informal sector), are Ugandan phenomenon not seen elsewhere in East Africa. The extent of night markets, and the ubiquity of food preparation and selling in open spaces, behind office buildings and 
hawking of used clothes and other wares in offices are all indications of the importance of the informal sector incomes to urban dwellers (Keller, 1996:19).

At the same time the country is experiencing on-going urban migration, increasing entry of women and children (Ssemogerere, 1996:13), and the automatic entry of illiterate people to the informal sector (Katabira, 1995:45), women inclusive. It can therefore be said that the growing number of women in the informal sector spins off from cultures, the nature of governance the country has undergone, effects of education, economic and political reforms in the country and the effect of poverty in the households. As documented by Uganda Women Entrepreneurs Association (UWEAL, 1999), a growing number of women in Uganda who are engaged in the informal sector are mostly self-employed. It is against that background that the study was conducted.

A survey of literature on women information provision in Africa brings to light some common characteristics. A study of women information needs in Nigeria reveals that most active women are in the age bracket of 30-50 years. A majority of them are illiterate. Their information needs relate to occupations like farming, food processing, and small businesses. Their sources of information tend to be radio, community leaders, relatives, friends and religious leaders. Being mostly illiterate, they rely mainly on oral media. Newspapers, books and other printed materials do not feature prominently as sources of information and yet a greater proportion of useful information, including that originating from Government, is disseminated through printed media (Nwagha, 1992:78-80). Mchombu (2000:62), however, brings to light women's need for information from two angles: from the viewpoint of institutions and from the women's own perspective.

From the institution's viewpoint, she observes, women need information: on business management and how to run businesses, information on where to acquire technical skills, information on finance; that is, where to get financial assistance and/or grants. Women also need legal information and specifically information about their rights, information on how to conduct feasibility studies, on different types of business so that they can avoid saturating a few trades in the sector, and the information about different sources of raw materials. In contrast, and from the women's perspective, she reports that women identify their information needs as: business management principles, ideas on business diversification, information on financial assistance, marketing information, etc.

Huyer (1997) cites the disabling factors to women's information access. These factors include: illiteracy, being taken out of school at an early age to save school fees, to marry, to ease their mother's workload or because of pregnancy which often occurs at an early age. She also cites poverty, low social status, the multiple roles of child bearing, farming and household chores, concentration in low-level employment, lack of autonomy and their lack of time, lack of radios, etc as other factors. Similar views are expressed in studies by Ngimwa, Ocholla and Ojiambo (1997) and findings from a recent study on information seeking by women in Melmoth, Kwazulu-Natal (Jiyane 2002).

\section{Methodology}

The study was conducted among Ugandan informal sector entrepreneurs. The survey and the critical incident research methods were used. The critical incident technique (CIT) is a term used to describe a flexible set of principles for qualitative research. It is a research technique originally developed during World War 2. Then it was used to identify effective and ineffective behaviours in a variety of military activities, and was subsequently developed as a tool for the systematic study of human behaviour and labelled critical incident technique as described in Flanagan's paper, published in 1954 (Fisher \& Oulton, 1997). The critical incident method was applied because it is effective and appropriate in seeking for information about the immediate past. The method entails asking the respondents to remember the most critical moments of their life in which they had experienced the most pressing problems in which information played an important part. Respondents were asked questions relating to situations in which they felt they were stuck in their businesses and needed information to resolve the problems.

The sample consisted of 117 women from five districts of the country, namely Lira, Masindi, Mbarara, Masaka and Kampala. Women from both rural and urban areas were studied. The informal sector is found in both urban and rural areas. This sample was extracted from the national study involving a bigger sample of 602 entrepreneurs in the informal sector (Odongo 2002).

Simple random sampling and snowballing techniques were applied in the study. Random sampling provided women in the study an equal opportunity to be selected. To do that and in every area the study was conducted, the number of eligible women was first established in consultation with local leaders or chairpersons. From them it was 
asked if all of them had adequate knowledge of issues that the study sought to examine. Having established that, the number met first was interviewed in proportion to the established population. Snowballing is a strategy that begins by asking well-suited people "who know a lot about something" (Patton, 1990:176). Snowballing was used as an appropriate strategy for locating information-rich cases for specific trades. The trades were traditional healing, and traditional birth supervising. In this study, lecturers from the Mbarara University of Science and Technology (MUST) Community Department were asked to propose the specific cases among the population that share the same experiences and characteristics. This strategy as suggested by Churchill (1991:1) relied on the researcher's ability to locate an initial set of respondents with the desired characteristics; then such individuals were used as informants to identify others with similar characteristics.

Secondary data relating to women's information needs in business was extracted from research reports, journals, books and the Internet.

The reliability of research instruments was tested through a pilot study conducted five months earlier (Odongo 2001) in one (east) region of the country. The instruments included the interview schedule and observation guide.

The interview schedule sought data relating to personal characteristics of women entrepreneurs, business characteristics and occupations, their views about the informal sector and characteristics of business units, as the basis for studying the information needs. The information needs and seeking behaviour, information access and flow, use and impact of information, constraints to accessing required information, and opinions about solving information constraints were the primary focus of the study.

Interviews were conducted in English or in the native languages of the subjects, depending on what each subject preferred. On average, an interview lasted for between forty minutes and one hour. Meanwhile, women's business activities were observed un-obstrucively as interviews were going on. A structured observation schedule was used for this purpose. The aim was to focus on specific aspects the study was interested in. The study was conducted between January 2001 to July 2001.

Women participating in the study came from a wide range of trades in the informal sector. These include: art and crafts (pottery, basket and mat making, knitting and crocheting, shoe making, art and crafts selling); food processing (baking, cooking, wine making, peanut processing, brewing, distilling and selling alcohol, coffee processing, grain milling, shea nut oil and milk processing). Other trades include blacksmithing, battery charging, tailoring, poultry keeping, piggery, traditional birth attending, fishing and fish trading, hairdressing, traditional healing, trading in herbal medicine, nursery bed (tree) management and stone crashing. This breadth of occupations is necessary because of the heterogeneous nature of the informal sector in Uganda. As a result, it is a disproportionate sample with some trades being represented more than others. This is because there are trades that are flooded while others are not. However, a number of studies such as that of the Swedish International Development Agency (SIDA); Ministry of Women in Development Culture and Youth (MoWIDCY); Government of Uganda (GoU) and National Council for Children (NCC); and Mbire in Elson \& Evers (1997:8) note that females appear to concentrate more on informal manufacturing, the food processing and clothing industries than the males. Other female intensive activities appear to be agro-processing, weaving, embroidery/needlework and food processing. Women also play a bigger role in informal services, processing food, tobacco, and selling newspapers (SIDA, 1996). Alongside the productive economy is another, unpaid economy, the reproductive economy. This is an economy which is female intensive according to Swedish International Development Agency (SIDA, 1996); GoU and NCC(1994), Uganda Women's Network (UWONET, 1995) and the World Bank (1993c).

\section{Results}

This section comprises information on demographics, information needs, seeking methods, sources, access, flow, use and constraints of information accessibility.

\section{Demographics}

Women of all ages are found in the informal sector. Of those women participating in the study, the biggest group clusters between $21-50$ years of age. Thirty-seven (31.6\%) of them are in the age bracket $31-40,33(28.2 \%)$ are in the age bracket 21-30. Women between 41-50 number 25 (21.4\%) while those between 51-60 are $13(11.1 \%)$. Above 60 there are few: 5 (4.3\%), while the adolescents, aged 20 and below, numbered only $4(3.4 \%)$.

About one-quarter of women participating in the study, 30 (25.6\%), have never been to school; $35(29.9 \%)$ have attempted or attained primary education; 30 (25.5\%) have received secondary school education; and $11(9.3 \%)$ have 
attained post secondary education but below diploma level. Three $(2.6 \%)$ have attained technical education at diploma level while $8(6.8 \%)$ have received university education.

$67(57.3 \%)$ women acquired skills through experience; 24 (20.5\%) completed apprenticeship. 21(17.9\%) had formal training, while $5(4.3 \%)$ received both formal and apprenticeship training.

The employment status shows that $81(69.2 \%)$ are engaged in their businesses full-time. They charge that if they do not, how would they keep their families? Involving themselves in some business is their most important route to raising money. $36(30.8 \%)$ are involved only on a part-time basis.

Relating to the length of time they have been involved in business, two-thirds, 38 (32.5\%), mention that they have been in the informal business for up to five years only. $29(24.8 \%)$ have been engaged for between 6-10 years, $33(28.2 \%)$ have worked for between 11-20 years, while 17 (14.5\%) had worked for more than twenty years. These results are not surprising, for a number of reasons. First, they show a pattern of age. There are activities that require young women to perform profitably like managing salons. And there are those where old age is respectable, like traditional birth attending and treating people with herbal medicine. Secondly, the period coincides precisely with the times in Uganda when there was political turmoil and the effects of structural adjustment that government adopted.

Considering that they were mostly young, the question was asked what they had been doing before getting into business. The findings show that $52(38.8 \%)$ were tilling land, $33(24.6 \%)$ had been at school, $15(11.2 \%)$ were in business already, $12(8.9 \%)$ were civil servants, $11(8.2 \%)$ were housewives, but as life became tougher and tougher, they had to fall in. Others had worked in different jobs before joining the informal sector. And $4(2.9 \%)$ had been children then.

Because they were found to have been working already, what factors had motivated them to switch to a new life in business was examined. The findings establish many factors. Income generation and employment, the responsibility of paying school fees for children, availability of market, poor crop yields, being idle, the need to supplement income, cattle rustlers, availability of raw materials and the experience of being able to meet personal obligations and save a little money were the leading factors. Some of them had specific knowledge and skills.

To get a clear picture of those with specific skills, responses are quoted according to occupations. Those who were tilling the land reported that there is a lot of free time after cultivating, so they have to do something to occupy themselves. Traditional birth attendants (TBAs) say that helping women to deliver babies is a family business. After doing the job one would likely obtain income and sometimes their names are given to the babies as a token of appreciation for being a good 'midwife.' One specifically said her mother is a TBA and so she picked it from her. One had been interested in becoming a doctor since childhood, but never made it. By helping women to deliver, she feels she is doing something closer to that profession. Others state that TBA work is essentially a way of assisting fellow women, since hospitals are far, and sometimes hospitals need a lot of money for their services. One recollects a situation when her daughter had labour problems. She had to help her to save her life or she would have died without help. Interestingly, many of them state that they follow in the footsteps of their mothers, while some say their mothers persuaded them to become TBAs as a form of business.

Traders had many responses as well. Twenty women state that they had entered into [informal] business to raise income since they lost their husbands, eighty of them said poverty forced them to join business, twenty had dropped out of school and ten were continuing. One said she was a stenographer, a job that is not well paid. Drug sellers say that they have training in nursing and therefore wanted to gain experience after training. And besides, drug selling is good because it takes one closer to communities and there is profit. And people prefer buying drugs nearby instead of going far. Hairdressers are mostly interested in making money. They had failed in life. Some of them became pregnant and married before completing school.

Categories of food processors are quite many, including wine making, grain milling, brewing and selling alcohol, cooking, extracting oil from shea nuts, etc. What is reproduced here is an aggregate of responses. Three women said they knew how to make wine from tropical fruits, which are readily available in Uganda in large quantities, and there a is market for the drinks and that is what triggered them into entrepreneurship. Seventy of them said they had skills in brewing and distilling alcohol and there was a ready market for the products. Besides, most of their businesses do not require much capital. Because of that they can easily get started and continue. Women in the north of the country take advantage of the shea nut tree that grows abundantly. This tree was nearly extinct because of good charcoal produced from it. But when an international (USA based) organisation, Co-operative Efforts of Voluntary Associations (COVOL), came to sensitise people to the economic value of this tree, people in the area realised that this tree is a money-maker. From then on, anyone found cutting down a shea nut tree would be fined about US\$30 
per tree. This is lot of money in villages. Besides charcoal, this tree has multiple usage. The fruit is eaten at home. Children wake up earlier than normal to pick and eat it before doing any work or going to school. The seeds are sold for manufacturing Vaseline, soap, creams, oil that is eaten, and washing powder. The mass remaining from oil extraction is poisonous, but is burnt by locals as a mosquito and termite repellent. This tree grows in northern Uganda, Ethiopia, Sudan, Nigeria, Ghana, Mali, Senegal and Burkina Faso. Tailors are utilising their skills, earning a living for self-sustenance. In the crafts, the main reason is income generation. To some it is a culture (Arabic and Muslim) that starts when a girl child is growing up. For most of the time Arabic culture promotes the use of mats for sitting on and for prayer, and a mat is given to a young girl who gets married to start her off in her new home. Abiba Juma (70+ years), of Sudanese origin and staying in the suburbs of Kigumba, Masindi District, stated:

Originally girls used not to be taken to school. Mat making and making of kutas (tray covers) was the only asset they were given. Eventually the craft became a way of killing time, earning money, keeping busy. With Africans there is no reading. Leisure time is spent by doing something productive. Unlike white people, Africans are preoccupied with things that satisfy immediate needs.

Women in the fishing sector mention that the fish business is easy, their former businesses were poor, they were tired of digging without sufficient returns, and there were no better jobs they could do with their little education.

\section{The information needs}

The most crucial information needs of women in the informal sector in Uganda include: information about better markets and marketing strategies for their products, sources of access to raw material and/or supplies at rather cheaper prices or at the current prices. This is followed by the need for information about the security of the country, sources of credit, advisory information and information about training opportunities. Women desire information about seasons, government regulations, and sources of equipment, advertising, and taxation and, to some extent, tenders and contracts. Table 1 provides insight into the information needs of women in the informal sector. The table shows the aggregate of the information needs.

Table 1 Information needs $(\mathrm{N}=117)$

\begin{tabular}{lcc}
\hline \multicolumn{1}{c}{ Type of information need } & Frequency $(\boldsymbol{f})$ & \% of respondents \\
\hline Market information & 91 & 78 \\
Sources of raw materials/supplies & 80 & 68 \\
Security of the area/country & 71 & 60 \\
Sources of credit & 68 & 58 \\
Sources of equipment & 59 & 50 \\
Advisory information & 57 & 49 \\
Training opportunities & 53 & 45 \\
Seasons & 44 & 38 \\
Government regulations & 39 & 33 \\
Advertising & 28 & 24 \\
Taxation & 28 & 24 \\
Tenders/contracts & 22 & 10 \\
\hline
\end{tabular}

NB: Respondents had multiple information needs each

However, there are specific needs in each trade. Women in craft trades need information about prices of mats in other places, how to make excellent mats, sources of genuine colouring matter (they complain that there are many fake colourings on the market). They need information on specific colours, sources of quality palm leaves, new designs, and general awareness. They too said that during the starting up stages of their business, information was very critical, and if they did not get that information, most likely they would be doing something else.

Women in food processing seek information about cheaper sources of foodstuffs, grains, business management skills, and where to get equipment for improved performance. In addition they face a problem of preserving food like peanuts after it has been ground. They ask why oil comes up the container and the paste settles down. They want information on how they could be assisted by specialists in the Department of Food Science at the National 
University so that they could be taught how to preserve food. Maintaining and improving quality and quick transportation of products are some of the issues forcing them to look for information.

Traditional birth attendants (folk midwives) said they look for information about safe methods of helping women with complications, to deliver where complicated cases were suspected, information about age of pregnancy, number of children already produced, and where to get gloves in case of emergencies. Furthermore, they seek information during labour, history of any complications in the past, and any health problems. They also look for information about loans.

Closer to TBAs are the herbalists (folk pharmacists). These say they require information about medicinal plants and their locations, where to get medicines for particular diseases, and prices of herbal medicine obtained from other practitioners.

Other traders such as drug sellers, tailors, poultry keepers and fishmongers also have specific information needs. Drug sellers (human medicine) say they often want information on how to use new drugs, where to replenish their supplies, the prices of new drugs, administration of drugs to the sick, and health problems affecting the critically ill patients. Tailors look for information at the beginning of the year about contracts for school uniforms, spares for sewing machines, new fashions, etc., while hairdressers are after information about new products for treating hair, the best cosmetics, new hairstyles, how to use new chemicals, and knowledge about chemicals themselves. Poultry keepers are after good markets, information about cheaper feeds, and treatments for sick birds. Women in fishing activities are mostly after information about good markets, and business skills.

Since the study covered a diversity of trades, there are other needs for information. Women need information on prices and pricing techniques, business trends, fashion designs, business management, product information, product packaging and quality control, modern methods of distilling alcohol, and modern methods of cooling milk are common concerns for information. They are also concerned with low skilled labour that could repair newly imported machines.

\section{Information seeking methods}

Considering that women carry out their businesses near their homes and bearing in mind their social responsibilities, and demographic characteristics, and also that undertaking business is a situation with many activities that require different types of information, it was a pertinent question to seek methods by which women access business information The aim was to establish whether there was any relation between social factors and the information seeking. The findings show that the methods used by women to seek information are those that do not take them far from their surroundings. Methods that cut across all of them are presented in Table 2 below. But in specific cases, a description of unique methods is also given.

Table 2 Information seeking methods $(\mathrm{N}=117)$

\begin{tabular}{lcc}
\hline \multicolumn{1}{c}{ How information was sought } & Frequencies $(f)$ & \% of respondents \\
\hline Using personal experience & 64 & 55 \\
Contacting people who know & 61 & 52 \\
Listening and talking to people & 55 & 47 \\
Asking a friend/relative/work neighbour & 48 & 41 \\
Visiting/asking customers & 29 & 25 \\
Using social networks & 23 & 20 \\
Listening to radio/TV & & \\
Asking Extension (Govt) Agents & 11 & 9 \\
Asking supervisor & 10 & 9 \\
Reading newspapers & 9 & 8 \\
Inquiring from educated people & 8 & 7 \\
Asking role models & 7 & 6 \\
Asking and listening to politicians & 3 & 3 \\
Seeking assistance from area councillors & 2 & 2 \\
Others & & \\
\hline
\end{tabular}

NB: At least each respondent had more than one way of seeking information. 
The findings indicate that a majority of respondents did not access external assistance or formal information systems. It is talking; listening and asking that predominate. The first seven methods of seeking information show that women do not go far from their environment to seek information. There is therefore a close relationship between social factors and information seeking methods among women in the informal sector. Women rely most on their personal experience as the prime source of information. Contacting people who know, and listening and talking to people were 'passive' ways by which they obtained information. Asking friends, customers and relying on social networks are the 'active' methods of getting information. The findings confirm why asking is rated high.

Listening to radio/TV, asking extension agents, work supervisors, politicians, and inquiring from educated people are methods that show something unique. All methods are informal. It is more explicit when it comes to the unclassified (others) category. Here the reported seeking patterns are asking the husband, observing something happening and replicating it, writing letters to friends, attending seminars and market days. Telephone contacts, travelling to sources of raw materials/suppliers and asking suppliers or the customers specific information are some of the methods of seeking information.

Information sources, access and flow.

Table 3 Sources of information $(\mathrm{N}=117)$

\begin{tabular}{lcc}
\hline \multicolumn{1}{c}{ Type of source } & Frequency $(\boldsymbol{f})$ & \% of respondents \\
\hline Word of mouth & 105 & 90 \\
Personal experience & 86 & 74 \\
Friends/relatives/neighbours & 67 & 57 \\
Radio/TV & 25 & 21 \\
Local councils & 20 & 17 \\
Workshops/seminars & 19 & 16 \\
Print media (newspapers, newsletters) & 16 & 14 \\
Area leaders (models, opinion leaders) & 8 & 7 \\
Orientation tours & 8 & 7 \\
Trade fairs & 7 & 6 \\
Business Associations & 7 & 6 \\
Educational institutions & 7 & 6 \\
Places of prayer & 6 & 5 \\
Cultural ceremonies & 4 & 3 \\
Others * & 15 & 13 \\
\hline
\end{tabular}

NB: Each respondent had more than one source of information

Women rely on the informal sources using informal channels to access business information. Findings show preference for receiving information directly by word of mouth. They too rely on personal experience and friends, relatives and neighbours. Use of radios is increasing due to their cheapness and availability. A handset is as cheap as US\$5, and maintaining them is equally cheap. Besides information, most of what is aired is music, which women also seem to like very much. Local councils are important sources of information. There is a local council right from the community level up to the national level. Women are represented at every level as required by law. Besides, information on community affairs also affects women, therefore more information is accessed in that way. In addition, some women read newspapers that are also available in local languages. Area leaders, by the nature of their positions, have a wealth of information that they share with people, including women. Table 3 shows the most utilised information sources.

Others* include Gatsby Club, traders, Uganda Small Scale Industries Association (USSIA), Uganda Manufacturers Association (UMA), customers, business informers, National Agricultural Organisation (NARO), Chairpersons of Associations, Uganda National Farmers Association, and different women's organisations, visiting of farmers, and fisheries committees 


\section{The use of information}

Of the 94 who answered this question, 86(92\%) say information helps them. The findings show a multiplicity of uses of information. It also depends on trades. But cutting across them all, doing business better than before is the immediate use and benefit of information. This means information facilitates decision making and/or problem solving. Women say they are more capable of fixing prices properly than they were before, are able to locate better markets, and run businesses more efficiently. They are able to promote marketing of their products, follow government rules and regulations, do work as required by the customers, adjust prices according to prevailing circumstances, acquire supplies fairly cheaply, and maintain quality. They realised that quality of information is an important input.

As a consequence of information use, women see their businesses expanding, more income being realised, more markets explored, and they are becoming creditworthy since creditors see them buying in bulk and also paying sooner for goods taken on credit.

\section{Constraints of accessing information}

Findings reveal that women experience several difficulties in accessing information. In all 327 frequencies were realised. Table 4 below represents these difficulties.

Table 4 Constraints $\quad(\mathrm{N}=117)$

\begin{tabular}{lcc}
\hline \multicolumn{1}{c}{ Type of constraint } & Frequencies $(f)$ & $\begin{array}{c}\text { \% of } \\
\text { respondents }\end{array}$ \\
\hline Not knowing where to get information & 69 & 59 \\
No specific place to get the required information & 52 & 44 \\
Takes time to get information & 45 & 38 \\
People with information do not release it easily & 43 & 37 \\
Inability to get the required information & 41 & 35 \\
Sometimes information I get is unreliable & 39 & 33 \\
Information is in languages I do not know & 10 & 9 \\
Most information is written. I am illiterate & 8 & 7 \\
I do not have time to look for information & 12 & 10 \\
Other* & 12 & 10 \\
\hline
\end{tabular}

NB: Each respondent had more than one constraint.

These findings give some leading ideas about difficulties of information provision to women in the informal sector in Uganda. Ignorance of information sources is an impediment to information access. Being busy all the time leaves no time for women to look for information. Lack of money, people concealing information, unreliability of information, illiteracy and attitudes are main constraints to information access.

In the unclassified (others) category, several interesting constraints were revealed. For example, witchdoctors dealing with broken bones say they are sometimes followed and intimidated by hospital doctors because patients escape from the hospital and go to them when they learn that their limbs will be amputated. According to these 'doctors', medical doctors think that witchdoctors are stealing their patients. Dealers in herbal remedies (traditional medicine) state that it is difficult to get information about the location of herbal plants. This is because government does not allow them to use forest trees as a source of their herbs. It is also because herbalists have been found to be destroying specific species of trees that already are endangered, through digging the roots or debarking certain trees.

\section{Discussion}

The issues concerning women and their part in the development process have been increasingly examined over the years on the African continent. Mchombu (2000:39-67), in a study of women's information needs in Botswana, concludes that women need information in all aspects of business activities. Information equips them with power, the power to choose, and to act in an informed manner. Appropriate information, she argues, empowers women towards actions that can transform their lives, and allows for a greater sense of independence. Information can be 
used in decision-making, solving problems and enhancing performance. It enables women to identify suitable products, equipment and materials, and to identify suitable suppliers. Women can use information in monitoring changes in their business activities and performance thereby identifying opportunities and threats. If used wisely, information reduces uncertainty, and enables them to identify alternative solutions to business problems.

Taking Botswana women as an example, what could be said of Uganda women in the informal sector? The findings reflect the demographic characteristics of respondents. Very few women who are doing business in the informal sector are well educated. Most women seek information informally. Social factors disrupt women's capacity to seek information.

The disabling factors include social restrictions such as those imposed by family demands, their spouses, illiteracy, ignorance and poverty at the personal level. At the institutional level, women do not know where to get information. These factors appear to corroborate the findings of Huyer (1997), who cites disabling factors to information access. These factors include: illiteracy, being taken out of school at an early age to save school fees, to marry, to ease their mother's workload, or because of pregnancy which often occurs at an early age. She also cites poverty, low social status, the multiple roles of child bearing, farming and household chores, concentration in lowlevel employment, lack of autonomy and lack of time, lack of radios, etc. as other factors. Qunta (1987:187) identifies illiteracy among women as one of the major factors hampering dissemination of information to women. Most of them are not able to write and read. That situation is compounded by inadequacy of communication networks. Ngimwa, Ocholla \& Ojiambo (1997:56), citing problems hindering Kenya women from accessing information, identify time constraints, low literacy levels, economic and cultural constraints, uneven distribution of information infrastructures as factors making it difficult for women to access information.

However, the importance of information and the means to transmit and disseminate it for development is well recognised. The International Development Research Centre's (IDRC) Gender and Information Group identifies the critical information issues for women. It lists (1) type of information - what kind, access to it, and gender consciousness, and (2) information technology process - availability of technologies to women, their ease of use, policy processes around these technologies, and their effects on women (Huyer, 1997). Some studies reveal that women have been successful once they are supported with the right information.

Since 1971, there has been fighting in Uganda. The people most affected are always women who are left behind to cater for children, and the elderly. They are always a majority in security camps that are hurriedly set up to try to safeguard the lives of those surviving. Unfortunately, conditions in camps are always far from being habitable. Women would love information that demands concrete projects and actions that express peace through dialogue, and the change from war to peace. Peace in the minds of women is most important, believing as they do that in most cases wars are caused by men.

As defined earlier, the informal sector of Uganda constitutes a business sector with tiny units involving very small sums of money for a majority of people. Women's need for information on sources of credit is a sign of limited knowledge of institutions that can help them. Women need money to expand their businesses. There are agencies that offer credit, but a majority of women are not aware of them. No directory of these institutions is available to help women learn about them. A directory of these institutions and making them widely known to women would be helpful.

Business requires a broad knowledge of many issues pertaining to markets, sources of raw materials, competitors, etc. Without such knowledge, business will not run well. It is for this reason that women need advisory information. The implications are that working capital is very small. It supports an argument that businesses are tiny and therefore operating at a subsistence level for most of them. Women are also willing to listen to advice. They are willing partners in development. Most importantly, they are very clever with their heads and hands.

It has been established that women in the informal sector have low education, a problem that stretches back to cultural preferences. For women to enter competitive ventures or even improve on the existing ones, training is essential. Training is a significant need for everybody including women because it is the way of gaining business competencies. UWEAL (1999) recognises that training for women is necessary because much of the business training in Uganda has been technical training for employment (job seekers), not technical training for business creation. According to this organisation, training for job seeking and job creation need to be combined, because the market demands a product/service with both skills from the entrepreneur. Women therefore require skills to do better in all business aspects and that is why they are voicing a need for training. It is why women need information about agencies that provide training. 
Women are interested in information about seasons because of their attachment to the land. In rainy seasons women are far fewer than men in the informal business in rural areas, because all days are spent in the gardens, and domestic work takes the remaining time. It has been calculated (Appleton, 1995; GoU \& NCC, 1995) that Ugandan women's working day, including reproductive as well as productive work, is estimated to range from 12 to 18 hours per day, with a mean of 15 hours. According to the World Bank (1993c: 27), women's working day is on average $20 \%$ longer than that of men. Also, some women are food processors. A poor season means low production and consequently the price of foodstuffs would be high and vice versa. When the prices of foodstuffs are high, there will be less business. Women therefore need information to plan carefully.

Government regulations are important for everybody. For women especially, government most of the time announces information about health issues like immunisation of children, about AIDS and how to cater for those afflicted; education of children, and women's programmes. These are important for women. Therefore, availability of information to them is crucial to enable them cope with such issues.

The need for information on sources of equipment comes from the fact that Uganda is a net importer for most of the equipment used in the country, although the informal sector manufactures some, albeit poor in quality. It is also because there are businesses that could improve if better equipment was provided. For example, women making wine would increase production, improve quality, and reduce manual labour and be able to compete on the market. Sources of information about importers and prices of these products are scarce. When these products are imported and advertised, it is mostly in newspapers, that a majority of women do not access or read.

Taxation is an important issue in Uganda today because of the small tax base and low incomes. But government is moving towards getting more people to pay taxes. Knowledge of tax regulations is important information women need.

\section{Conclusion}

There is a positive trend towrds women's empowerment in Uganda and a growing number of women-owned businesses exist. There are many instruments such as the national constitution, and several women-related policies that have been enacted by government to help women improve. There is a lot of goodwill from government and donor agencies to support women in development. However, women in Uganda still face many problems in accessing business information; and most likely all types of information. Existing formal information institutions have not been beneficial to a majority of women. There are few information resource centres in the country where women can read or meet to share experiences. The multiplicity of local languages, illiteracy and lack of modern knowledge about where they are located limits information exploitation. Women's organisations find it difficult to distribute information or monitor women's activities throughout the country due to lack of transport and equipment. Many of these organisations rely on volunteers who are also handicapped to a large extent. Attempts by women to inform each other is basically through informal channels and within their own areas. Women's NGOs use forums for women to work together. Even these are informally organised and are not regular. Librarianship of poverty (Mchombu, 1982:241-250) and poverty of librarianship (Sturges, 2001:38-48) appear to be the major problems. There is a need for African Librarianship and information work to become meaningful. There is a need for introspection, and opening up the minds to realities if change is to be achieved.

The study aimed at gaining insights into the information needs of women in the informal sector. This study has established that women need information. It has also established that women face a lot of problems in accessing information. To move away from information scarcity to some level of information provision, Huyer (1997) suggests active participation of women in the identification and definition of their information needs. More research and dissemination of research findings is critical in this subject. She argues that women's choice of mechanisms and processes to meet these needs is critical for their productive participation and dissemination of information as well as the definition of and access to information they need. And, in accordance with strategic objective F.3 (Providing business services and access to markets, information and technology to low-income women) of the Beijing Conference (1995), Government in co-operation with NGOs and the private sector should: provide outreach programmes to inform low-income women of opportunities for market and technology access. They should provide assistance in taking advantage of such opportunities. The starting point should be to disseminate information about successful women entrepreneurs in both traditional and non-traditional economic activities and the skills necessary to achieve success; to facilitate networking and the exchange of information. They should also develop programmes 
for training and retraining, particularly in new technologies and affordable services to women in business management, product development, financing, production and quality control, marketing and the legal aspects of business (Licuanan, 1995). An early priority should be a project to commission in-depth case studies, which will quantify women issues and remove gender distortions and barriers.

Furthermore, to be able to provide information to women, the following needs exist:

- To increase girl-child opportunities to education as a way of building for the future of better informed women. The existing policy of awarding girls extra 1.5 points on entry to university should be expanded to lower levels of education to increase the number of girls in schools. It would reduce the incidence of illiteracy that has been identified as one of the bottlenecks to information access. It would also address the issue of ignorance, since there is a close relation between literacy and better information absorption. In the long run, the number of educated women capable of breaking cultural barriers would increase.

- Gender policies should be understood by all women, including those at the grassroots. Making them aware of these policies would create a need for more information, thereby developing their information absorption capacity.

- To develop new methodologies for documenting and disseminating of information to women, as well as improving the existing ones. Information workers would need retraining in the art of documenting and packaging feminist literature. Such training should adopt realistic models that are easy to maintain, and move away from those that are expensive and difficult to maintain. Fresh and innovative ideas are required to make information provision to women a reality. Models such as public libraries that have not been fully successful should be analysed and appropriate aspects from them integrated to new models. Prevalent models (oral) should also be analysed and useful components integrated into new methods of providing information.

- To empower and train women, in the art of collecting, documenting and disseminating information at all levels, especially at the community level. This would be the role of NGOs and Government departments dealing with gender issues. The ideas should focus on where there is no librarian or community information service, what should be done to collect relevant information and make it available to women who need it. An answer to such questions should provide a suitable methodology for training women in the art of dealing with information that affects them.

- To encourage women to seek and receive information, especially published. Liberation of the mind is the most important aspect. Through education, seminars, meetings, etc. women should be encouraged to meet the challenges of doing work without sufficient information.

- To break cultural barriers and make women active seekers and users of information. Assertiveness by women themselves and continued gender mainstreaming by government and society as a whole, and education, would be some of the ways to overcome barriers to information. What is most important at this stage would be the implementation of those aspects and policies that support women's efforts.

- To encourage gender officers, educational institutions and NGOs dealing in women's affairs to conduct research on the information needs and provision to women and finding practical ways of disseminating information, especially through workshops, community activities and in the classrooms.

- To expand and/or establish women's documentation information centres as a means of collecting women-related information. Such centres would provide information as and when needed. Redefining the role of a public library to address community information needs, and especially those of women, would be a positive direction. This is Government's responsibility through appropriate legislation.

Information workers should simplify:

- information repackaging and the use of local languages would be one of the ways women in Uganda can be helped with information. Translation of relevant textsand an increase in the publication of feminist literature would go a long way to alleviate the problem of information scarcity. Women's publishing houses clearly supported by government would be an opportunity to look into. Rural presses would also be another, and

- women should take an active interest in gathering information for themselves.

\section{References}

Appleton, S. (1995). Women-headed households and poverty: an Empirical deconstruction for Uganda. Oxford: Centre for the study of African Economics.

Basirika, E. (1994). Structural adjustment the informal sector In Empowerment, poverty and structural adjustment in Uganda. Edited by J.C. Munene. Kampala: Friedrich Ebert Foundation.

Churchill, G.A. (1991). Marketing research: methodological foundations. 5th ed. Forthwith: Dryden

Elson, D. \& Evers, B. (1997). Gender aware country economic reports: working paper number 2, Uganda. Manchester, UK:

Graduate School of Social Science, University of Manchester. 
Epstein, T. (1993). Female petty entrepreneurs and their multiple roles. In Allen, S. Truman, C. eds Women in business: perspectives on women entrepreneurs. London: Routledge.

Evans, A. (1992). A review of the rural labour market in Uganda. Kampala:World Bank.

Barton, T. \& Wamai G. (1994). Equity and vulnerability: a situation analysis of women, adolescents and children in Uganda, Government of Uganda (GoU) and the National Council for Children (NCC) 1994, Kampala.

Jiyane, GV (2002) An exploratory study of the information availability and utilization by the rural women of Melmoth, Kwazulu-Natal. University of Zululand (MLIS Dessertation, unpublished)

Huyer, S. (1997). Supporting women's use of information technologies for sustainable development Rec. 01/09/10 from http:// www.idrc.ca/acacia/outputs/womenicts.html/.

Katabira, S. (1995). A study of various informal sector activities: A case study of Katwe area. Kampala: Makerere University. (B.A. SS Dissertation, unpublished).

Keller, B. (1996). Uganda country gender profile. Stockholm: SIDA; Department for East and West Africa and the Department for Policy and Legal Issues.

Kigongo-Bukenya, IMN (1996). Strategies of co-ordinating women information activities with reference to the role of IsisWICCE In Provision of information to women in Uganda, A Report of the workshop held at Africa Hall, Makerere University, Kampala Uganda 19-21, August 1996.

Licuanan, P.B. (1995?). Propose Beijing declaration to accompany the draft platform for Action. Rec. Oct. 1999 from http:// www.iisd.ca/4wcw/dpa-003.html.

Lwanga, E. (1996). Reaching the grassroots women through information provision. In Provision of information to women in Uganda, A Report of the workshop held at Africa Hall, Makerere University, Kampala Uganda 19-21, August 1996.

Mchombu, C.M. 2000 Information needs of women in small businesses in Botswana in International Information \& Library Review. 32:39-67.

Mchombu, K. (1982). On librarianship of poverty. Libri, 32:241-250.

Mensink, M. (1995). Women and finance in Uganda: low income women; respected business partners..?

Ministry of Gender, Labour and Social Development, (1999). The convention on the elimination of all forms of discrimination against women (CEDAW). Kampala: MoGLSD.

Mitter, S.(2000) Women in knowledge societies. Rec.01/09/10 from http:///www.women action.org/gkii/swasti.html.

Musoke, M. (1996). The role of information in redressing gender related social imbalances In Provision of information to women in Uganda, A Report of the workshop held at Africa Hall, Makerere University, Kampala Uganda 19-21, August 1996.

Mwaka, V.; Mugenyi, M. \& Banya, G. (1994). Women in Uganda Uganda: a profile; final research report. Kampala: Makerere University.

Ngimwa, P., Ocholla, D.N. \& Ojiambo, J.P. (1997) Media accessibility and utilisation by Kenyan rural women In Information \& Library Review 29: 45-66.

Nwagha, G.K.N. (1992). Information needs of rural women in Nigeria. Information Development, 8, 2:76-82.

Odongo, IR (2001) A study of the information needs and uses of the informal sector in Uganda. Preliminary Findings. LIBRES: Library and Information Science Research Electronic Journal, 11(1) (visit: http://aztec.lib.utk.edu/libres1 In1/Ocholla.htm .accessed on 30 April 2001)

Odongo, IR (2002) A study of the information needs and uses of the informal sector of Uganda. University of Zululand, South Africa (unpublished Ph.D. thesis)

Ojiambo Ochieng, R. (1996). Revisiting Beijing: key issues for information provision to women in Uganda. In Provision of information to women in Uganda, A Report of the workshop held at Africa Hall, Makerere University, Kampala Uganda 1921, August 1996.

Patton, M.Q. (1990). Qualitative evaluation and research methods. 2 ed. London: Sage.

Plowman, P. (2001) From the wings to the centre stage: the challenge of gender mainstreaming In Development Update: a quarterly journal of the South African National NGO Coalition and INTERFUND. 167-183.

Portrer, F. (1996). The need for documenting women's realities In Provision of information to women in Uganda, A Report of the workshop held at Africa Hall, Makerere University, Kampala Uganda 19-21, August 1996.

Qunta, C. (1987) Women in South Africa. Johannesburg: Skotaville.

Paik, Y-J Women's development and information on women in Korea Rec.09/10/99 from http://ifla.org/Ivifla64/112-122e.html.

Rwegasira, D.I. \& Walter, V. comps (1998). Facing the challenge: Women socio-economic and political empowerment in Kenya, Tanzania and Uganda. Dar es Salaam: Friedrich Ebert Stiftung.

Snyder, M. (2000) Women in African economies: from burning sun to boardroom. Kampala: Fountain Publishers.

Ssemogerere, G. (1996). Employment and labour market during adjustment in Eastern and Southern Africa: The case of Uganda: An overview. Kampala: ILO.

Sturges, P. (2001). The poverty of librarianship: an historical critique of public librarianship in Anglophone Africa. Libri, $51: 3848$.

United Nations (2000) Why focus on poor women and how best to serve them. Rec. 09/01 from http:// www.womensworldbanking.org/english/2000/2500.htm..Uganda women entrepreneurs Association Ltd (UWEAL) (1999). Newafrica.com.

World Bank, (1993c). Growing out of poverty. New York: Washington. 